\title{
EFEKTIVITAS KELEMBAGAAN DESA DALAM PRAKTIK DEMOKRASI DI DESA KELANGDEPOK, PEMALANG JAWA TENGAH
}

\author{
The Local Institutional Effectiveness in the Democratic's Practice at the Desa Kelangdepok, \\ Pemalang, Central Java
}

\author{
Sofi Nur Ariyati *) dan Sofyan Sjaf \\ Departemen Sains Komunikasi dan Pengembangan Masyarakat, Fakultas Ekologi Manusia, IPB
}

*)Email: sofi.ariyati@gmail.com

\begin{abstract}
Institutional effectiveness in the practice of country chief elections is influenced by four factors, namely institutional factors, member institutions factors, support facilities factors, and social-community factors. On institutional effectiveness, in terms of which factors are more influential on the level of effectiveness. Then, at each stage and the overall practice of country chief elections, it will see which is the most dominant factor. You will see the members of which are more effective among members of formal and informal members. The method used is the method of quantitative and qualitative data supported. The results showed that member institutions factors have major influence on the level of effectiveness. In the preparation phase, the factors that have a major influence factor is the support facilities factors. Meanwhile, at the implementation stage, the fourth factor is not the most significant influence. For the whole practice, support facilities factors is the most influential factor as the same as in the preparation stage. The performance of members who more effective in the overall is the formal members. Referring to the results, informal members are expected to be more involved again, and formal members further enhanced performance.
\end{abstract}

Keywords: democracy, institutional, village

\begin{abstract}
ABSTRAK
Efektivitas kelembagaan desa dalam praktik pemilihan kepala daerah dipengaruhi oleh empat faktor, yaitu faktor kelembagaan, faktor anggota kelembagaan, faktor sarana/fasilitas pendukung, dan faktor sosialmasyarakat. Pada efektivitas kelembagaan, faktor mana yang lebih berpengaruh pada tingkat efektivitas. Kemudian, pada masing-masing tingkatan dan keseluruhan praktik pemilihan kepala daerah, akan terlihat faktor yang paling dominan. Akan terlihat bahwa keanggotaan kelembagaan adalah faktor yang paling efektif diantara anggota formal dan informal. Metode yang digunakan adalah metode kuantitatif dan kualitatif data. Hasil penelitian ini menunjukkan bahwa faktor anggota kelembagaan mempunyai pengaruh paling signifikan terhadap tingkat efektivitas. Pada tahap persiapan, faktor yang memiliiki pengaruh paling signifikan adalah faktor sarana/fasilitas pendukung. Sementara itu, pada tahap penerapan. Keempat faktor tersebut tidak berpengaruh signifikan. Untuk keseluruhan praktik, faktor sarana/fasilitas pendukung merupakan faktor yang paling berpengaruh sama seperti pada tahap persiapan. Kinerja anggota yang lebih efektif pada keseluruhan praktik adalah anggota formal. Berdasarkan hasil penelitian, anggota informal diperkirakan menjadi lebih dilibatkan lagi dan anggota formal kinerjanya lebih ditingkatkan.
\end{abstract}

Kata kunci : demokrasi, desa, kelembagaan

\section{PENDAHULUAN}

\section{Latar Belakang}

Indonesia mempunyai sejarah perjalanan panjang tentang demokrasi. Hal ini ditunjukkan dari beberapa peralihan periode demokrasi yang terjadi, yakni periode 1945-1959 yang dikenal sebagai masa demokrasi parlementer, periode 1959-1965 yang dikenal sebagai masa demokrasi terpimpin, periode 1966-1998 yang dikenal sebagai masa demokrasi Pancasila era orde baru, dan periode 1999-sekarang yang dikenal sebagai masa demokrasi Pancasila era reformasi
(Rikard dan Susanto, 2005). Praktik demokrasi semakin marak terjadi pada masa demokrasi Pancasila era reformasi tahun 1999 sampai sekarang, seperti adanya pemilihan Calon Legislatif (Caleg), pemilihan Gubernur, pemilihan Walikota, pemilihan Bupati, dan pemilihan Kepala Desa.

Sebagaimana dalam praktiknya, demokrasi melibatkan berbagai macam aktor dan lembaga dari tingkat nasional hingga tingkat lokal. Pelaksanaan demokrasi memuat aspek kelembagaan yang merupakan keutamaan dari berlangsungnya praktik politik yang demokratis. Hal ini ditunjukkan dengan adanya lembaga perwujudan 
demokrasi dalam penyelenggaraan pemerintahan desa yang tertuang dalam Undang-Undang Republik Indonesia Nomor 6 Tahun 2014 tentang Desa, yang berfungsi untuk menampung dan menyalurkan aspirasi masyarakat, yakni Badan Permusyawaratan Desa (BPD) serta Pemerintah Desa sebagai unsur penyelenggara pemerintahan desa.

Selain lembaga tersebut, munculnya civil society atau lembaga informal seperti kelompok perkumpulan pemuda, kelompok agama, dan sebagainya juga ikut menyumbang partisipasi dan melakukan pengawasan terhadap proses jalannya pemerintahan serta praktik dari penyelenggaraan pemerintahan desa itu sendiri. Salah satu hasil penelitian Hudayana (2003) memaparkan bahwa perkumpulan warga Bantul juga terlibat dalam penyusunan peraturan daerah (Perda) tentang pemerintahan desa yang demokratis. Lain halnya di Purworejo, perkumpulan warga lebih kooperatif dalam pesta demokrasi (berbagai bentuk pemilihan) yang diadakan oleh pemerintah desa serta aktif dalam mensosialisasikan kesadaran kritis.

Praktik demokrasi yang dipilih di tingkat lokal ialah pemilihan Kepala Desa, hal ini dikarenakan bahwa pemilihan Kepala Desa merupakan salah satu bentuk irisan praktik demokrasi yang berasaskan musyawarah dan gotong-royong dalam pencapaian dan pelaksanaan keputusan (nilai demokrasi murni) dengan aspek partisipasi/keikutsertaan masyarakat dalam pengambilan keputusannya (nilai demokrasi secara universal). Praktik ini juga menjadikan aspek kelembagaan sebagai unit penyelenggara yang melibatkan elemen masyarakat sebagai pihak yang berpartisipasi dalam proses teknis pelaksanaan (panitia) maupun pemberian hak suara.

Selanjutnya, fakta di lokasi penelitian juga menunjukkan adanya kondisi pemerintahan desa yang kritis. Kondisi pemerintahan yang memprihatinkan ini memicu kelembagaan-kelembagaan desa, baik formal maupun informal melakukan gerakan untuk menyelenggarakan kembali proses pemilihan Kepala Desa. Merujuk pada pemaparan-pemaparan yang telah disampaikan dan juga fakta di lokasi penelitian yang mendukung, penting bagi peneliti untuk meneliti tentang efektivitas kelembagaan dan membandingkan kelembagaan mana yang lebih efektif, apakah kelembagaan formal atau kelembagaan informal. Desa yang menjadi lokasi penelitian ialah Desa Kelangdepok. Desa ini terletak di Kecamatan Bodeh, Kabupaten Pemalang, Provinsi Jawa Tengah.

\section{Masalah Penelitian}

Masalah utama penelitian dalam kajian ini yaitu adalah sejauhmana keefektifan kelembagaan desa dalam praktik pemilihan Kepala Desa.

Adapun secara lebih rinci permasalahan yang menjadi fokus penelitian ini yaitu:

1. Faktor manakah yang lebih berpengaruh pada keefektifan kelembagaan?

2. Faktor manakah yang lebih berpengaruh pada praktik pemilihan kepala desa?

3. Adakah pengaruh tingkat efektivitas kelembagaan dengan proses berjalannya praktik pemilihan kepala desa secara keseluruhan?

4. Manakah lembaga yang lebih efektif dalam praktik demokrasi desa?

\section{Tujuan Penelitian}

Penelitian ini bertujuan untuk:

1. Menganalisis faktor manakah yang lebih berpengaruh pada efektivitas kelembagaan.

2. Menganalisis faktor dari efektivitas kelembagaan manakah yang lebih berpengaruh dalam pelaksanaan praktik demokrasi.

3. Menganalisis pengaruh tingkat efektivitas kelembagaan dengan pelaksanaan praktik demokrasi.

4. Menganalisis lembaga manakah yang lebih efektif dalam pelaksanaan praktik demokrasi, apakah lembaga formal atau lembaga informal.

\section{PENDEKATAN TEORITIS}

\section{Demokrasi dan Demokrasi Pedesaan}

Abraham Lincoln mengatakan bahwa demokrasi adalah sistem pemerintahan yang diselenggarakan "dari rakyat, oleh rakyat, dan untuk rakyat", atau dengan kata lain kedaulatan (kekuasaan tertinggi) berada di tangan rakyat. Lain halnya dengan pandangan Held (1987) yang dikutip oleh Hadiwinata (2005) arti demokrasi pada masa itu ialah demokrasi langsung, dimana rakyat secara langsung dan bersama-sama lewat suatu pertemuan menentukan keputusan-keputusan politik yang mendasar.

Prijono \& Tjiptoherijanto (2012) menambahkan bahwa pola-pola demokrasi tradisional/ aras desa dilambangkan dengan musyawarah dalam pencapaian keputusan dan gotong-royong dalam pelaksanaan keputusannya. Proses pencapaian keputusan dalam masyarakat oleh orang-orang desa diartikan sebagai proses yang menuntun masyarakat ke persetujuan atau pertentangan dengan usulan yang diajukan orang-orang desa. Pencapaian keputusan secara bersama ini mempertimbangkan tiga aspek, yaitu permulaan atau prakarsa, pengesahan, dan juga pelaksanaan.

\section{Kelembagaan}

Utami, Molo, Widiyanti (2011) menyatakan bahwa kelembagaan dari aspek formal merupakan gambaran/ deskripsi potret dari aspek regulative institusi formal yang terdiri dari batas yuridiksi, peraturan, sanksi dan monitoring. Kelembagaan menyediakan pedoman dan sumber daya untuk bertindak, sekaligus batasan-batasan dan hambatan untuk bertindak. Fungsi kelembagaan adalah untuk tercapainya stabilitas dan keteraturan.

Kelembagaan formal di aras desa merujuk pada organisasi yang berada di bawah tanggung jawab atau komando pemerintahan desa, dimana menurut Peraturan Pemerintah Nomor 72 Tahun 2005 tentang Desa, pasal 1 menyebutkan Pemerintahan Desa adalah penyelenggaraan urusan pemerintahan oleh Pemerintah Desa dan Badan Permusyawaratan Desa dalam mengatur dan mengurus kepentingan masyarakat setempat berdasarkan asalusul dan adat istiadat setempat yang diakui dan dihormati dalam sistem Pemerintahan Negara Kesatuan Republik Indonesia.

Kemudian, institusi informal dikaji berdasarkan aspek normative dan aspek cultural-kognitif. Kelembagaan menyediakan pedoman dan sumber daya untuk bertindak, 
sekaligus batasan-batasan dan hambatan untuk bertindak. Fungsi kelembagaan itu sendiri ialah untuk tercapainya stabilitas dan keteraturan (Utami, Molo, Widiyanti 2011).

Putnam (1996) yang dikutip oleh Hadiwinata (2005) mendefinisikan civil society sebagai segala bentuk kehidupan sosial yang terorganisir dan terbuka bagi semua kalangan, menganut prinsip sukarela, dan tumbuh secara mandiri. Civil society juga merupakan tempat perbedaan kepentingan dinegosiasikan sehingga kehadirannya dapat meningkatkan kemampuan pemerintah dalam merepresentasi kepentingan dan sekaligus memperluas partisipasi politik.

Selanjutnya, Alagappa (2004) yang masih dikutip oleh Hadiwinata (2005) mengemukakan bahwa civil society akan mengembangkan demokrasi ketika ia memfasilitasi pembentukan budaya politik demokratis, meminta kepada pemerintah untuk mempertanggung jawabkan setiap kebijakannya, dan mendorong masyarakat untuk melakukan partisipasi politik.

Sosok masyarakat sipil yang dimaksud secara operasional ialah mencakup institusi-institusi non-pemerintah yang berada di masyarakat yang mewujudkan diri melalui organisasi, perkumpulan atau pengelompokan sosial dan politik yang berusaha untuk membangun kemandirian seperti organisasi sosial dan keagamaan, lembaga swadaya masyarakat (LSM), paguyuban, kelompok-kelompok kepentingan, dan sebagainya yang juga bisa mengambil jarak dan menunjukkan otonomi terhadap negara atau berhubungan dengan proses penyelenggaraan pemerintahan desa. Konsep civil society inilah yang dijadikan dasar pemikiran konsep lembaga informal.

\section{Efektivitas Kelembagaan}

Teori efektivitas muncul dari pendapat seorang ahli yakni Soekanto (tidak ada tahun) yang dikutip oleh Khairulludin (2010), beliau mendefinisikan teori efektivitas di bidang hukum. Efektif atau tidaknya suatu hukum ditentukan oleh 4 (empat) faktor. Pertama; faktor hukumnya sendiri (undangundang). Kedua; faktor penegak hukum, yakni pihak-pihak yang membentuk maupun menerapkan hukum. Ketiga; faktor sarana atau fasilitas yang mendukung penegakan hukum. Keempat; faktor masyarakat dan kebudayaan, yakni lingkungan dimana hukum tersebut berlaku atau diterapkan dan berkaitan dengan kesadaran dan kepatuhan hukum masyarakat. Teori efektivitas di bidang hukum ini kemudian ditransformasikan menjadi teori efektivitas pada sebuah kelembagaan.

Merujuk dari pemaparan di atas, dapat dirumuskan bahwa konsep efektivitas kelembagaan adalah upaya pencapaian tujuan berdasarkan sumberdaya yang tergantung pada kelembagaan itu sendiri (memuat tentang peraturan), kinerja dari anggota kelembagaan, sarana/fasilitas yang mendukung, serta lingkungan dimana kelembagaan tersebut tumbuh yakni meliputi sifat masyarakat yang hidup di sekitar dan juga kebudayaan yang ada di masyarakat.

\section{Kerangka Pemikiran}

Lembaga-lembaga yang terlibat dalam praktik demokrasi ada tiga, yakni lembaga desa yang bersifat formal seperti Badan Permusyawaratan Desa (BPD), Pemerintah Desa, dan Karang Taruna, serta lembaga desa yang bersifat informal seperti paguyuban warga desa, dan organisasi masyarakat keagamaan. Perbedaan sifat kelembagaan ini akan menentukan seberapa jauh lembaga tersebut dapat berpartisipasi dan berpengaruh pada pelaksanaan praktik demokrasi yang dijalankan. Hal ini dikarenakan sejauhmana pencapaian tujuan dari masing-masing lembaga formal dan informal dalam praktik demokrasi akan menunjukkan efektivitas dari kedua kelembagaan tersebut.

Pengukuran efektivitas akan dilihat dari beberapa indikator yang meliputi faktor kelembagaan, faktor anggota kelembagaan, faktor sarana/fasilitas pendukung, serta faktor sosial-masyarakat. Selanjutnya, merujuk pada UndangUndang Republik Indonesia Nomor 6 Tahun 2014 tentang Desa, proses pemilihan Kepala Desa dibagi menjadi dua tahapan, yakni tahap persiapan dan tahap pelaksanaan.

Tahap persiapan meliputi pembentukan panitia pemilihan, penjaringan dan penyaringan berkas bakal calon Kepala Desa, mengumumkan calon Kepala Desa yang berhak dipilih kepada masyarakat, serta pelaksanaan kampanye dari para calon Kepala Desa. Tahap pelaksanaan meliputi proses pemungutan suara, proses perhitungan suara, pelaporan hasil perhitungan suara, dan pelantikan Kepala Desa yang terpilih. Pemaparan dari hal inilah yang merujuk pada rumusan kerangka analisis yang dibuat sebagai berikut :

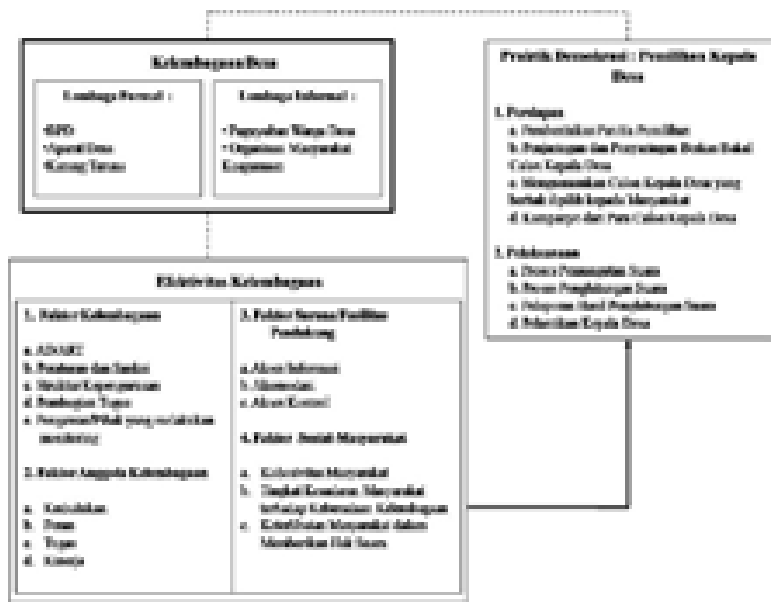

Gambar 1 Kerangka pemikiran

Keterangan:

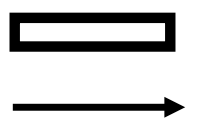

$$
\begin{aligned}
& \text { : Unit analisis } \\
& \text { : Mempengaruhi } \\
& \text { : Dilihat dari }
\end{aligned}
$$

\section{Hipotesis}

1. Terdapat pengaruh signifikan faktor tertentu terhadap efektivitas kelembagaan

2. Terdapat pengaruh signifikan faktor tertentu efektivitas kelembagaan terhadap praktik demokrasi desa

3. Terdapat pengaruh efektivitas kelembagaan terhadap praktik demokrasi desa

4. Kelembagaan formal lebih efektif dibandingkan dengan kelembagaan informal 


\section{PENDEKATAN LAPANG}

Penelitian dilakukan menggunakan metode kuantitatif (kuesioner yang dianalisis dengan aplikasi SPSS) dengan pendekatan penelitian sensus dan didukung metode kualitatif (wawancara tidak terstruktur, wawancara mendalam, observasi, dan analisa data sekunder terkait). Populasi pada penelitian ini adalah panitia pemilihan Kepala Desa dengan jumlah 39 orang, Desa Kelangdepok, Kecamatan Bodeh, Kabupaten Pemalang, Jawa Tengah. Adapun unit penelitiannya yaitu anggota kelembagaan formal dan informal yang terdaftar sebagai panitia. Penelitian dilakukan di Desa Kelangdepok, Kecamatan Bodeh, Kabupaten Pemalang, Jawa Tengah pada bulan April 2014.

\section{GAMBARAN UMUM LOKASI PENELITIAN}

\section{Kondisi Geografis dan Ekonomi}

Desa Kelangdepok adalah salah satu dari sembilan belas desa yang terdapat di Kecamatan Bodeh, Kabupaten Pemalang, Jawa Tengah. Desa ini termasuk dalam daerah dataran rendah yang memiliki ketinggian rata-rata antara 6-15 meter di atas permukaan laut. Curah hujan rata-rata selama 1 (satu) tahun di desa ini adalah $302 \mathrm{~mm}$. Desa Kelangdepok terbagi menjadi 2 Dusun yakni Dusun Kelang dan Dusun Depokan. Kemudian terbagi menjadi 4 RW (Rukun Warga), dan 18 RT (Rukun Tetangga). Adapun batas-batas wilayah Desa Kelangdepok adalah sebagai berikut:

$\begin{array}{lll}\text { - } & \text { Sebelah utara } & \text { : Desa Sragi } \\ \text { - } & \text { Sebelah timur } & \text { : Desa Pendowo } \\ \text { - Sebelah selatan } & \text { : Sungai Comal } \\ \text { - Sebelah barat } & \text { : Desa Muncang }\end{array}$

Adapun luas wilayah Desa Kelangdepok adalah sekitar 279 ha. Sebagian besar lahan di Desa Kelangdepok digunakan untuk persawahan. Sebanyak 51 persen (142,3 ha) wilayah desa merupakan persawahan. Selain wilayah persawahan tersebut, lahan di desa digunakan untuk bangunan pemukiman warga masyarakat, infrastruktur desa, dan juga fasilitas lainnya.

Jumlah Kepala Keluarga (KK) di Desa Kelangdepok adalah $955 \mathrm{KK}$. Total penduduk seluruhnya adalah 2815 jiwa yang terdiri dari 1453 jiwa penduduk perempuan dan 1362 jiwa penduduk laki-laki. Sedangkan jumlah warga masyarakat yang tercatat dalam daftar pemilih tetap adalah sebanyak 2 537 jiwa. Jumlah keluarga yang bekerja di sektor pertanian sebanyak 329 keluarga, sedangkan jumlah keluarga yang anggota keluarganya ada buruh tani sebanyak 476 keluarga.

Hal ini menunjukkan bahwa sumber utama penghasilan sebagian besar masyarakat Desa Kelangdepok adalah sektor pertanian terutama di pertanian padi. Sisa jumlah lainnya bekerja di sektor perdagangan yang meliputi usaha warung kelontong, usaha warung makanan dan minuman, sektor industri di usaha konveksi, serta sebagai kalangan pegawai negeri sipil. Selanjutnya, rata-rata tingkat pendidikan warga masyarakat Desa Kelangdepok adalah lulusan jenjang Sekolah Menengah Atas.

\section{Karakteristik responden}

Responden pada penelitian ini berjumlah 39 orang.
Responden adalah anggota kelembagaan yang tercatat sebagai panitia pemilihan Kepala Desa di Desa Kelangdepok pada tahun 2010. Pembagian anggota kelembagaan yang menjadi panitia pemilihan Kepala Desa ialah menurut status keanggotaan responden dalam sebuah kelembagaan tertentu. Responden akan dibedakan menjadi responden yang berasal dari kelembagaan formal desa dan juga yang berasal dari kelembagaan informal desa.

Pada penelitian ini, jumlah responden yang berasal dari kelembagaan formal adalah sebanyak 27 orang yang terdiri dari 9 anggota BPD, 9 perangkat desa, 6 anggota karang taruna, 1 anggota LPMD, dan 2 anggota dari pihak RT/ RW. Jumlah responden yang berasal dari kelembagaan informal adalah sebanyak 12 orang yang terdiri 10 anggota paguyuban warga desa, dan 2 anggota dari tokoh perempuan yang juga merupakan anggota dari organisasi masyarakat keagamaan.

Tingkat pendidikan dari anggota lembaga formal yang berjumlah 27 orang terdiri dari lulusan perguruan tinggi sebesar 51.85 persen (14 orang), lulusan SMA 11 sebesar 40.74 persen (11 orang), dan juga lulusan SMP sebesar 7.41 persen (2 orang). Sedangkan untuk tingkat pendidikan dari anggota lembaga informal yang berjumlah 12 orang, terdiri dari lulusan SD sebesar 58.33 persen (7 orang), lulusan SMP sebesar 33.33 persen (4 orang), dan lulusan perguruan tinggi sebesar 8.34 persen (1 orang).

\section{Profil Kelembagaan Formal dan Kelembagaan Informal Desa}

\section{Profil Kelembagaan Formal Desa}

\section{a. Badan Permusyawaratan Desa (BPD)}

Jumlah anggota BPD Desa Kelangdepok ialah sebanyak 9 (sembilan) orang, yang terdiri dari seorang ketua, seorang sekretaris, seorang wakil ketua, dan 6 (enam) orang lainnya sebagai anggota. Pemilihan anggota BPD ini melalui musyawarah bersama berdasarkan kemampuan dan kompetensi yang dimiliki, dimana kandidat dari pengurus mewakili dusun, ataupun mewakili Rukun Warga (RW) yang ada di Desa Kelangdepok.

Jumlah RW yang ada sebanyak 4 (empat) RW, kandidat anggota BPD meliputi 2 (dua) orang dari RW 01, 2 (dua) orang dari RW 02, 3 (tiga) orang dari RW 03, dan 2 (dua) orang dari RW 04. Perbedaan jumlah kandidat dari RW 03 dengan RW lainnya, yakni 3 (tiga) orang disebabkan karena wilayah RW 03 lebih luas dibandingkan dengan RW yang lainnya, sehingga keterwakilan warga tidak terlalu timpang.

\section{b. Lembaga Pemberdayaan Masyarakat Desa (LPMD)}

Merupakan salah satu lembaga kemasyarakatan sebagai mitra kerja pemerintah desa untuk mengelola, merencanakan dan melaksanakan pembangunan dengan menggali swadaya gotong-royong masyarakat desa. Lembaga ini juga bertugas untuk menyusun rencana pembangunan yang berpartisipatif, menggerakkan swadaya gotong-royong masyarakat, dan melaksanakan pengendalian pembangunan. Jumlah anggota LPMD Desa Kelangdepok ialah sebanyak 9 (sembilan) orang, yang terdiri dari seorang ketua, seorang sekretaris, seorang bendahara, dan 6 (enam) orang lainnya sebagai anggota. 


\section{c. Aparat Desa/Perangkat Desa}

Merupakan unsur penyelenggara pemerintahan desa guna membantu Kepala Desa dalam melaksanakan tugas dan wewenangnya. Dalam pelaksanaan tugasnya, perangkat desa bertanggung jawab penuh terhadap Kepala Desa. Jumlah perangkat desa yang ada di Desa Kelangdepok adalah sebanyak 9 (sembilan) orang belum termasuk sekretaris desa, yang terdiri dari seorang bendahara desa, seorang polisi desa, seorang lebe, seorang kaur pembangunan, seorang kaur pelayanan masyarakat, dan empat kepala dusun.

\section{d. Karang Taruna}

Merupakan salah satu lembaga kemasyarakatan yang menjadi wadah pengembangan generasi muda yang tumbuh dan berkembang atas dasar kesadaran dan rasa tanggung jawab sosial dari, oleh dan untuk masyarakat terutama generasi muda di wilayah desa/kelurahan atau komunitas adat sederajat. Karang Taruna di Desa Kelangdepok bernama "Mekar". Jumlah anggota Karang Taruna yang ada di Desa Kelangdepok ialah sebanyak 10 (sepuluh) orang, yang terdiri dari seorang ketua, seorang sekretaris, seorang bendahara, dan 7 (tujuh) orang lainnya sebagai anggota.

\section{Profil Kelembagaan Informal Desa}

\section{a. Paguyuban Warga}

Merupakan salah satu lembaga yang dibentuk oleh kalangan masyarakat setempat, juga menjadi wadah bagi masyarakat untuk menyalurkan aspirasinya tentang isuisu yang berhubungan dengan berbagai bentuk praktik penyelenggaraan pemerintahan desa. Nantinya akan diteruskan sampai lembaga formal desa. Anggota dari paguyuban ini terdiri dari berbagai kalangan masyarakat, seperti masyarakat biasa, kalangan profesi, atau mantan pejabat desa sekalipun. Jumlah dari anggota paguyuban ini pun lebih dari 10 (sepuluh) orang.

\section{b. Organisasi Masyarakat Keagamaan}

Merupakan lembaaga atau perkumpulan warga yang tidak terikat dengan wewenang resmi dari pemerintah desa, dan berkumpul berdasarkan kesamaan kepercayaan dan keyakinan yang bertujuan untuk menjalin tali silaturahmi dan persaudaraan. Lembaga ini juga menjadi wadah bagi anggotanya untuk mengembangkan aspirasinya, dan dapat pula ikut mengawasi serta membantu pelaksanaan praktik penyelenggaraan pemerintahan desa. Perkumpulan ini meliputi perkumpulan Muhammaddiyah, perkumpulan Nahdatul Ulama (NU), perkumpulan Fathayat, perkumpulan Muslimat, dll. Biasanya pada perkumpulan Fathayat dan perkumpulan Muslimat, hampir seluruh anggotanya terdiri dari kalangan masyarakat golongan tua.

\section{HASIL DAN PEMBAHASAN}

\section{Faktor Pengaruh Efektivitas}

Efektivitas kelembagaan merupakan upaya pencapaian tujuan yang dipengaruhi oleh beberapa faktor, yakni faktor kelembagaan, faktor anggota kelembagaan, faktor sarana/ fasilitas pendukung, serta faktor sosial-masyarakat.

\section{Pengaruh Faktor Kelembagaan}

Hal-hal yang dilihat adalah sejauhmana penerapan dan pelaksanaan komponen-komponen yang bersifat abstrak dan yuridis, seperti AD/ART, peraturan dan sanksi, struktur kepengurusan, pembagian tugas, serta pihak yang melakukan monitoring kegiatan.

Tabel 2. Jumlah dan Persentase Responden Menurut Status Kelembagaan dan Besaran Pengaruh Faktor Kelembagaan

\begin{tabular}{|c|c|c|c|c|c|c|c|c|}
\hline \multirow{3}{*}{$\begin{array}{l}\mathrm{S} t \text { a t u s } \\
\text { Ke le m - } \\
\text { bagaan }\end{array}$} & \multicolumn{6}{|c|}{ Faktor Kelembagaan } & \multirow{2}{*}{\multicolumn{2}{|c|}{ Total }} \\
\hline & \multicolumn{2}{|c|}{ Besar } & \multicolumn{2}{|c|}{ Sedang } & \multicolumn{2}{|c|}{ Rendah } & & \\
\hline & $\mathrm{n}$ & $\%$ & $\mathrm{n}$ & $\%$ & $\mathrm{n}$ & $\%$ & $\mathrm{~N}$ & $\%$ \\
\hline For-mal & 8 & 20.51 & 19 & 48.72 & 0 & 0.00 & 27 & 69.23 \\
\hline $\begin{array}{l}\mathrm{I} \\
\text { for-mal }\end{array}$ & 0 & 0.00 & 12 & 30.77 & 0 & 0.00 & 12 & 30.77 \\
\hline Total & 8 & 20.51 & 31 & 79.49 & 0 & 0.00 & 39 & 100.00 \\
\hline
\end{tabular}

Berdasarkan Tabel 2, faktor kelembagaan mempunya pengaruh yang sedang terhadap tingkat efektivitas kelembagaan secara keseluruhan. Kategori sedang ini dikarenakan bahwa pada hal pelaksanaan dan penerapan alokasi dana kegiatan terbentur dengan sebuah masalah dana desa yang tidak bisa mencukupi pengeluaran yang ada. Faktor kelembagaan menjadi tergolong pengaruh sedang juga didukung dengan adanya pernyataan dari salah satu informan yakni sebagai berikut:

“...memang ada sedikit kendala pada anggaran dana desa mbak, dikarenakan pada saat itu keuangan desa sedang mengalami krisis, sehingga panitia harus mencari dana tambahan untuk menutupi kekurangan yang ada, tetapi untungnya kami masih bisa menjalankan rencana kegiatan-kegiatan yang ada, begitu mbak..." (AST, tokoh masyarakat desa)

\section{Pengaruh Faktor Anggota Kelembagaan}

Perihal yang dilihat adalah sejauhmana kedudukan, peranan, tugas, dan kinerja dijalankan oleh anggota sesuai dengan pedoman dan instruksi yang ada.

Tabel 3. Jumlah dan Persentase Responden Menurut Status Kelembagaan dan Besaran Pengaruh Faktor Anggota Kelembagaan

\begin{tabular}{|c|c|c|c|c|c|c|c|c|}
\hline \multirow{3}{*}{$\begin{array}{l}\text { Status } \\
\text { Kelem- } \\
\text { ba-gaan }\end{array}$} & \multicolumn{6}{|c|}{ Faktor Anggota Kelembagaan } & \multirow{2}{*}{\multicolumn{2}{|c|}{ Total }} \\
\hline & \multicolumn{2}{|c|}{ Besar } & \multicolumn{2}{|c|}{ Sedang } & \multicolumn{2}{|c|}{ Rendah } & & \\
\hline & $\mathrm{n}$ & $\%$ & $\mathrm{n}$ & $\%$ & $\mathrm{n}$ & $\%$ & $\mathrm{~N}$ & $\%$ \\
\hline For-mal & 15 & 38.46 & 12 & 30.77 & 0 & 0.0 & 27 & 69.23 \\
\hline $\begin{array}{l}\text { Infor- } \\
\text { mal }\end{array}$ & 1 & 2.56 & 11 & 28.21 & 0 & 0.0 & 12 & 30.77 \\
\hline Total & 16 & 41.02 & 23 & 58.98 & 0 & 0.0 & 39 & 100.00 \\
\hline
\end{tabular}

Berdasarkan tabel 3, faktor anggota kelembagaan mempunyai pengaruh sedang terhadap tingkat efektivitas kelembagaan. Kategori sedang ini dikarenakan bahwa beberapa panitia yang memiliki kedudukan seperti seorang ketua, sekretaris, dan bendahara BPD, maupun seorang ketua, sekretaris, serta bendahara panitia pemilihan, mempunyai tingkat akses yang lebih tinggi dibandingkan 
lainnya, sehingga tingkat keaktifannya berbeda, hal ini didukung dengan adanya pernyataan dari salah satu informan yakni sebagai berikut:

$$
\begin{aligned}
& \text { “..tugas-tugas yang berkaitan dengan syarat } \\
& \text { administratif dan perberkasan memang lebih } \\
& \text { ditanggung jawabkan kepada aparat desa, karena } \\
& \text { untuk urusan semacam ini aparat desa lebih } \\
& \text { memahami dan menguasainya. Tetapi, dalam hal } \\
& \text { pelaksanaan teknis tugas-tugas, anggota panitia yang } \\
& \text { bukan pejabat desa pun menjalankan dengan begitu } \\
& \text { baikjuga. Jadi sebenarnya, untuk keseluruhan panitia } \\
& \text { tergolong aktif semua mbak...” (ASR, ketua RW) }
\end{aligned}
$$

\section{Pengaruh Faktor Sarana/Fasilitas Pendukung}

\begin{tabular}{|c|c|c|c|c|c|c|c|c|}
\hline \multirow{3}{*}{$\begin{array}{l}\text { Status } \\
\text { Kelem- } \\
\text { bagaan }\end{array}$} & \multicolumn{6}{|c|}{$\begin{array}{l}\text { Faktor Sarana/Fasilitas } \\
\text { Pendukung }\end{array}$} & \multirow{2}{*}{\multicolumn{2}{|c|}{ Total }} \\
\hline & $\begin{array}{l}\mathrm{Be}- \\
\text { sar }\end{array}$ & Seda & & Renc & & & & \\
\hline & $\mathrm{n}$ & $\%$ & $\mathrm{n}$ & $\%$ & $\mathrm{n}$ & $\%$ & $\mathrm{~N}$ & $\%$ \\
\hline For-mal & 21 & 53.8 & 6 & 15.4 & 0 & 0.0 & 27 & 69.2 \\
\hline Informal & 2 & 5.2 & 10 & 25.6 & 0 & 0.0 & 12 & 30.8 \\
\hline Total & 23 & 59.0 & 16 & 41.0 & 0 & 0.0 & 39 & 100.0 \\
\hline
\end{tabular}

Terkait dengan segala sesuatu yang dapat digunakan untuk memperlancar sebuah kegiatan atau mencapai sebuah maksud dan tujuan. Pada faktor sarana/fasilitas pendukung, hal yang akan dilihat adalah sejauhmana akses informasi, akomodasi, dan akses kontrol dijalankan.

Tabel 4. Jumlah dan Persentase Responden Menurut Status Kelembagaan dan Besaran Pengaruh Faktor Sarana/Fasilitas Pendukung

Berdasarkan tabel 4, faktor sarana/fasilitas pendukung mempunyai pengaruh besar terhadap tingkat efektivitas kelembagaan. Hal ini dikarenakan bahwa hampir semua komponen dari faktor sarana/fasilitas pendukung dijalankan sesuai dengan kebutuhan dan berjalan semestinya tanpa ada kendala dan hambatan yang berarti. Selain itu, hampir semua responden menjalankan teknis kegiatan yang berkaitan dengan keseluruhan komponen faktor sarana dengan begitu sangat baik. Berbagai macam alternatif digunakan untuk pelaksanaan komponen faktor sarana tanpa mengganggu deadline yang telah ditetapkan, dan juga bisa merata ke seluruh kalangan masyarakat. Penjelasan tersebut didukung dengan adanya pernyataan dari salah satu informan yakni sebagai berikut:

$$
\begin{aligned}
& \text { “...bentuk penyebaran informasinya cukup beragam } \\
& \text { ya mbak, pada waktu itu pengumuman ditempelkan di } \\
& \text { berbagai lokasi, seperti kantor desa, warung, masjid, } \\
& \text { mushola. Pokoknya di tempat-tempat strategis gitu } \\
& \text { loh mbak. Selain itu, juga disebarkan melalui forum- } \\
& \text { forum masyarakat seperti pertemuan paguyuban, dan } \\
& \text { juga forum pengajian di semua golongan. Biasanya } \\
& \text { hampir semua aparat desa sama BPD mengetahui } \\
& \text { semua kegiatan penyebaran itu, juga yang bukan } \\
& \text { pejabat desa pun ikut membantu dan pelaksanaannya } \\
& \text { pun cukup baik ya mbak.... (AHS, kepala dusun) }
\end{aligned}
$$

\begin{tabular}{|c|c|c|c|c|c|c|c|c|}
\hline \multirow{3}{*}{$\begin{array}{l}\text { Status } \\
\text { Kelem- } \\
\text { ba-gaan }\end{array}$} & \multicolumn{6}{|c|}{ Faktor Sosial-Masyarakat } & \multirow{2}{*}{\multicolumn{2}{|c|}{ Total }} \\
\hline & \multicolumn{2}{|c|}{ Besar } & \multicolumn{2}{|c|}{ Sedang } & \multicolumn{2}{|c|}{ Rendah } & & \\
\hline & $\mathrm{n}$ & $\%$ & $\mathrm{n}$ & $\%$ & $\mathrm{n}$ & $\%$ & $\mathrm{~N}$ & $\%$ \\
\hline For-mal & 1 & 2.56 & 26 & 66.67 & 0 & 0.0 & 27 & 69.23 \\
\hline Informal & 0 & 0.00 & 12 & 30.77 & 0 & 0.0 & 12 & 30.77 \\
\hline Total & 1 & 2.56 & 38 & 97.44 & 0 & 0.0 & 39 & 100.00 \\
\hline
\end{tabular}

\section{Pengaruh Faktor Sosial-Masyarakat}

Hal ini terkait dengan sekumpulan manusia yang hidup terorganisasi, saling berhubungan dan saling berinteraksi satu sama lain di lingkungan kelembagaan tersebut terbentuk, dan juga di saat kelembagaan tersebut melakukan kegiatan tertentu.

Tabel 5. Jumlah dan Persentase Responden Menurut Status Kelembagaan dan Besaran Pengaruh Faktor Sosial-Masyarakat

Berdasarkan Tabel 5, faktor sosial-masyarakat mempunyai pengaruh sedang terhadap tingkat efektivitas kelembagaan. Kategori pengaruh sedang ini dikarenakan bahwa meski hampir semua komponen dari sosial-masyarakat berjalan dengan semestinya tanpa ada kendala dan hambatan yang berarti, tetapi masih ada beberapa perselisihan kecil yang terjadi di kalangan masyarakat, walaupun tidak sampai menyebabkan konflik pecah. Perselisihan ini terjadi antarpendukung calon dalam bentuk pertengkaran mulut saja dan masih dalam taraf wajar. Penjelasan tersebut didukung dengan adanya pernyataan dari salah satu

\begin{tabular}{|c|c|c|c|c|}
\hline \multicolumn{3}{|c|}{ Faktor } & thitung & Sig \\
\hline \multicolumn{3}{|c|}{ Kelembagaan } & 1,144 & ,261 \\
\hline bagaan & Anggota & Kelem- & 12,914 &, 000 \\
\hline Penduku & $\underset{\text { Ing }}{\text { Sarana }}$ & silitas & 2,582 & ,014 \\
\hline & Sosial-M & arakat &, 036 & ,971 \\
\hline
\end{tabular}
informan yakni sebagai berikut:

“...memang ada sedikit permasalahan pada waktu itu mbak, pendukung Kepala Desa yang lama dengan para pendukung Kepala Desa yang akan mencalon terlibat semacam perselisihan/cekcok kecil tentang masalah Kepala Desa lama yang menyelewengkan dana desa. Kemudian perselisihan antarpendukung calon juga ada. Tetapi ya tidak sampai perkelahian terbuka gitu mbak, masih pada taraf wajar. Dan dari pihak panitia bisa mengkondisikannya..."(AST, tokoh masyarakat desa)

Kemudian, berdasarkan analisis data statistik, dari keempat faktor efektivitas yang terdiri dari faktor kelembagaan, faktor anggota kelembagaan, faktor sarana/fasilitas pendukung, dan faktor sosial-masyarakat, faktor yang mempunyai pengaruh paling signifikan adalah faktor anggota kelembagaan. Hal ini dikarenakan nilai t hitung faktor anggota kelembagaan memiliki nilai paling tinggi dibandingkan nilai t hitung faktor lainnya.

Hasil analisis data tersebut menunjukkan bahwa hipotesis penelitian pertama yakni terdapat pengaruh signifikan faktor terhadap efektivitas kelembagaan dinyatakan terbukti. 

Faktor yang Berpengaruh terhadap Praktik Pemilihan
Kepala Desa

Praktik pemilihan Kepala Desa dibagi menjadi tahap persiapan dan tahap pelaksanaan. Tahap persiapan meliputi; pembentukan panitia pemilihan, penjaringan dan penyaringan berkas bakal calon Kepala Desa, pengumuman calon Kepala Desa yang berhak dipilih, dan kampanye dari para calon Kepala Desa. Tahap pelaksanaan sendiri terdiri dari proses kegiatan pemungutan suara, proses kegiatan perhitungan suara, pelaporan hasil perhitungan suara, serta proses kegiatan pelantikan Kepala Desa.

Kemudian, faktor-faktor efektivitas yang terdiri dari faktor kelembagaan, faktor anggota kelembagaan, faktor sarana/ fasilitas pendukung, dan faktor sosial-masyarakat akan dikaitkan dengan sejauhmana pelaksanaan tahap persiapan berjalan, sejauhmana pelaksanaan tahap pelaksanaan berjalan, serta sejauhmana praktik pemilihan Kepala Desa yang berjalan secara keseluruhan.

Tabel 6. Persentase Besaran Faktor-Faktor Efektivitas Terhadap Praktik Pemilihan Kepala Desa

\begin{tabular}{llll}
\hline \multirow{2}{*}{ Faktor Efektivitas } & \multicolumn{3}{l}{ Tahap Praktik Pemilihan Kepala Desa (\%) } \\
\cline { 2 - 4 } & Persiapan & Pelaksanaan & Keseluruhan \\
\hline Kelembagaan & 8 & 18 & 13.0 \\
$\begin{array}{l}\text { Anggota Kelem- } \\
\text { bagaan }\end{array}$ & 26 & 46 & 36.0 \\
$\begin{array}{l}\text { Sarana/Fasilitas } \\
\text { Pendukung }\end{array}$ & 65 & 34 & 49.5 \\
Sosial-Masyarakat & 1 & 2 & 1.5 \\
\hline
\end{tabular}

Berdasarkan tabel 6 , terlihat bahwa pada tahap persiapan, faktor sarana/fasilitas pendukung memiliki persentase paling besar yakni 65 persen, yang kemudian disusul dengan faktor anggota kelembagaan sebesar 26 persen, faktor kelembagaan sebesar 8 persen, dan untuk faktor sosial-masyarakat sebesar 1 persen. Hal ini menunjukkan bahwa faktor sarana/fasilitas pendukung mempunyai persentase paling besar terhadap tahap persiapan.

Pengaruh faktor sarana/fasilitas pendukung yang tergolong besar pada tahap persiapan dibuktikan dengan berjalannya akses informasi, akomodasi, dan kontrol yang baik terkait dengan penyelenggaraan pemilihan Kepala Desa. Akses informasi, penyebaran informasi yang berkaitan dengan persiapan pemilihan Kepala Desa berjalan dengan sangat baik, informasi yang diberikan bersifat transparan dan terbuka. Selain itu, media penyebaran informasinya juga cukup beragam seperti melalui selebaran yang ditempelkan di tempat-tempat yang strategis, penyaluran dari bapak RT/ RW dan kepala dusun setempat. Penyaluran informasi pun dilaksanakan di berbagai perkumpulan warga masyarakat. Di samping itu, akses kontrol masyarakat terhadap rangkaian proses persiapan pemilihan Kepala Desa terbilang baik, dari awal pembukaan pendaftaran calon Kepala Desa sampai kampanye calon Kepala Desa, masyarakat benarbenar mengawal dan mengontrol kinerja panitia agar tidak terjadi sebuah ketimpangan. Hasil ini selaras dengan hasil perhitungan analisis data statistik yang dilaksanakan, faktor yang mempunyai pengaruh paling signifikan adalah faktor sarana/fasilitas pendukung.

Pada tahap pelaksanaan, faktor anggota kelembagaan memiliki persentase paling besar yakni 46 persen, yang kemudian disusul dengan faktor sarana/fasilitas pendukung sebesar 34 persen, faktor kelembagaan sebesar 18 persen, dan untuk faktor sosial-masyarakat sebesar 2 persen. Kontribusi besaran persentase faktor anggota kelembagaan ini dikarenakan bahwa semua anggota panitia bekerja sesuai dengan pembagian tugas yang ada, serta pelaksanaan koordinasi antaranggota yang cukup baik pula pada teknis lapangan tahap pelaksanaan. Meski demikian, jika dilihat pengaruh signifikansi dari keempat faktor, menurut hasil perhitungan analisis data statistik, keempat faktor efektivitas tidak ada yang memberikan pengaruh paling signifikan.

Sementara untuk keseluruhan praktik, faktor sarana/ fasilitas pendukung mempunyai persentase besar terhadap praktik pemilihan Kepala Desa yakni sebesar 49.5 persen. Hasil ini juga selaras dengan hasil perhitungan analisis data statistik yang menunjukkan bahwa faktor yang mempunyai pengaruh paling signifikan adalah faktor sarana/fasilitas pendukung. Besaran nilai t hitung faktor sarana/fasilitas pendukung yakni 4.483 lebih besar dari besaran nilai t tabel 2.776, dan juga lebih besar dibandingkan dengan besaran $t$ hitung faktor yang lain.

\begin{tabular}{crr}
\hline Faktor & t hitung & Sig \\
\hline Kelembagaan & 1,486 &, 147 \\
$\begin{array}{c}\text { Anggota Kelem- } \\
\text { bagaan }\end{array}$ &, 331 &, 743 \\
$\begin{array}{c}\text { Sarana/Fasilitas } \\
\text { Pendukung } \\
\quad \text { Sosial-Mas- } \\
\text { yarakat }\end{array}$ & 4,483 &, 000 \\
\hline
\end{tabular}

*) hasil analisis data statistik

Selanjutnya, berdasarkan hasil analisis data statistik pula, kontribusi pengaruh keempat faktor efektivitas (faktor kelembagaan, faktor anggota kelembagaan, faktor sarana/ fasilitas pendukung, dan faktor sosial-masyarakat) terhadap praktik pemilihan Kepala Desa sebesar 53.5 persen.

Meski keempat faktor tersebut hanya berpengaruh sebesar 53.5 persen terhadap praktik pemilihan Kepala Desa, tetapi jika dilihat dari nilai signifikansinya, terdapat satu faktor tertentu yang memiliki pengaruh signifikan dibandingkan dengan faktor yang lainnya. Hasil ini sudah bisa menjawab hipotesis penelitian saya yang kedua, yakni terdapat pengaruh signifikan faktor tertentu efektivitas kelembagaan pada praktik demokrasi desa, dalam hal ini praktik pemilihan Kepala Desa.

\section{Efektivitas Kelembagaan dalam Praktik Pemilihan Kepala Desa}

Tingkat efektivitas kelembagaan merupakan hasil perpaduan dari tingkat penerapan keempat faktor-faktor efektivitas. Jika keempat faktor memiliki tingkat penerapan yang baik, maka tingkat efektivitas kelembagaan pun akan tergolong dalam kategori baik pula. Pengkategorian tingkat efektivitas dibagi menjadi tiga yakni kategori rendah, sedang, dan tinggi. Tingkat efektivitas kelembagaan ini akan dikaitkan dengan proses praktik pemilihan Kepala Desa secara keseluruhan, mulai dari tahap persiapan sampai tahap pelaksanaan. Kategori pelaksanaan praktik pemilihan Kepala Desa juga dibagi menjadi tiga kategori, yakni kategori tidak baik/buruk, sedang, dan baik. 
Tabel 7. Persentase Besaran Efektivitas dengan Besaran Praktik Pemilihan Kepala Desa

\begin{tabular}{lllll}
\hline \multirow{2}{*}{ Efektivitas } & \multicolumn{2}{l}{ Praktik Pemilihan Kepala Desa (\%) } & \multirow{2}{*}{ Total } \\
\cline { 2 - 4 } & Baik & Sedang & Tidak Baik & \\
\hline Tinggi & 38.5 & 0.0 & 0 & 38.5 \\
Sedang & 35.9 & 5.6 & 0 & 61.5 \\
Rendah & 0.0 & 0.0 & 0 & 0.0 \\
Total & 74.4 & 5.6 & 0 & 100.0 \\
\hline
\end{tabular}

Berdasarkan tabel 7, besaran persentase kategori antara kategori efektivitas kelembagaan dengan kategori praktik pemilihan tidak berbanding lurus, hasil yang terlihat menunjukkan bahwa kategori efektivitas kelembagaan tergolong sedang, dan kategori praktik pemilihan tergolong baik Untuk besaran nilai persentase tertingginya, nilai tertinggi persentase tingkat efektivitas dan nilai persentase praktik pemilihan sama-sama tergolong dalam kategori yang tinggi ataupun baik. Perbedaan ini dapat diartikan bahwa keduanya tidak saling mempengaruhi.

Tetapi, pada hasil pengolahan data statistik, menunjukkan hasil keterkaitan pengaruh antara keduanya, dimana ingkat efektivitas kelembagaan memiliki pengaruh sebesar 21.6 persen terhadap praktik pemilihan Kepala Desa. Kemudian, tingkat efektivitas kelembagaan mempunyai pengaruh terhadap praktik pemilihan Kepala Desa. Hal ini ditunjukkan dengan besaran nilai signifikansi 0.03 lebih kecil dari nilai alpha yang digunakan yakni 0.05 . Besarnya persentase pengaruh tidak melebihi angka 50 persen, namun hasil tersebut sudah dapat menjawab hipotesis penelitian yang ketiga, yakni terdapat antara pengaruh efektivitas kelembagaan terhadap praktik pemilihan Kepala Desa.

Selanjutnya, untuk menganalisis manakah kelembagaan yang lebih berperan dominan atau yang lebih efektif antara kelembagaan formal dan kelembagaan informal desa terhadap praktik pemilihan Kepala Desa, maka dilaksanakan uji t beda independent. Hal yang diperhatikan dari uji ini adalah perbedaan nilai rata-rata dan juga nilai signifikansi yang tertera. Hasil uji beda ini menunjukkan bahwa nilai rata-rata dari tingkat efektivitas dan proses pemilihan Kepala Desa secara keseluruhan antara anggota kelembagaan formal dan anggota informal mempunyai besaran nilai rata-rata yang berbeda. Hasil tersebut juga menunjukkan bahwa besaran nilai rata-rata anggota kelembagaan formal desa yang terlibat menjadi panitia pemilihan Kepala Desa lebih besar dari anggota informal desa.

Pada faktor-faktor efektivitas kelembagaan, terlihat bahwa anggota formal lebih efektif dibandingkan anggota informal, hal ini dibuktikan dengan besaran nilai rata-rata anggota formal lebih besar dibandingkan besaran nilai rata-rata anggota informal. Tetapi, dapat dilihat pula bahwa perbedaan besaran nilai rata-rata tersebut tidak terpaut jauh. Hal ini disebabkan oleh tingkat akses, kemauan, dan kemampuan mengakses yang berbeda diantara keduanya.

Selain itu, proporsi panitia pemilihan antara anggota formal dan anggota informal juga tidak seimbang, dimana jumlah anggota formal lebih mendominasi. Perbedaan proporsi ini dikarenakan kurangnya tingkat kepercayaan anggota formal terhadap anggota informal. Hasil yang terlihat pada efektivitas kelembagaan juga menunjukkan bahwa anggota formal masih menjadi unit yang lebih efektif dibandingkan dengan anggota informal.

Tabel 8. Perbandingan Nilai Rata-Rata Antara Kelembagaan Formal dan Kelembagaan Informal dalam Efektivitas Kelembagaan

\begin{tabular}{|c|c|c|c|c|c|}
\hline \multirow[b]{2}{*}{$\begin{array}{l}\text { Status } \\
\text { Kelem- } \\
\text { ba gaan }\end{array}$} & \multicolumn{4}{|c|}{ Faktor-Faktor Efektivitas } & \multirow[b]{2}{*}{$\begin{array}{l}\text { Efektivi- } \\
\text { tas }\end{array}$} \\
\hline & $\begin{array}{l}\text { K e le m - } \\
\text { bagaan }\end{array}$ & $\begin{array}{l}\text { Anggota } \\
\text { K e } 1 \text { e m - } \\
\text { bagaan }\end{array}$ & $\begin{array}{l}\text { Sarana/ } \\
\text { F a sil- } \\
\text { i t a s } \\
\text { P e n - } \\
\text { dukung }\end{array}$ & $\begin{array}{l}\text { So s i a l- } \\
\text { M a s - } \\
\text { yarakat }\end{array}$ & \\
\hline Formal & 2.30 & 2.56 & 2.78 & 2.04 & 2.56 \\
\hline $\begin{array}{l}\text { In for - } \\
\text { mal }\end{array}$ & 2.00 & 2.08 & 2.17 & 2.00 & 2.00 \\
\hline
\end{tabular}

Tabel 9. Perbandingan Nilai Rata-Rata Antara Kelembagaan Formal dan Kelembagaan Informal dalam Praktik Pemilihan Kepala Desa

\begin{tabular}{|c|c|c|c|}
\hline $\begin{array}{l}\text { Status } \\
\text { Kelemba }\end{array}$ & \multicolumn{2}{|c|}{$\begin{array}{l}\text { Tahap Praktik Pemilihan } \\
\text { Kepala Desa }\end{array}$} & $\begin{array}{l}\text { Praktik Pemilihan } \\
\text { Kepala Desa }\end{array}$ \\
\hline & Persiapan & Pelaksanaan & \\
\hline Formal & 2.89 & 2.67 & 2.96 \\
\hline Informal & 2.25 & 2.08 & 2.25 \\
\hline
\end{tabular}

Kemudian, pada tahap persiapan dan tahap pelaksanaan juga menunjukkan hasil yang tidak jauh berbeda. Terlihat bahwa anggota formal lebih efektif dibandingkan anggota informal, hal ini dibuktikan dengan besaran nilai ratarata anggota formal lebih besar dibandingkan besaran nilai rata-rata anggota informal. Tetapi, dapat dilihat pula bahwa perbedaan besaran nilai rata-rata tersebut tidak terpaut jauh. Hal ini disebabkan oleh perbedaan tingkat akses pada tahap persiapan yang sering berkaitan dengan urusan administratif dan urusan berkas-berkas lainnya. Dalam urusan seperti itu, sudah pasti anggota formal lebih menguasai dan juga lebih bisa mengontrolnya. Pada tahap pelaksanaan pun, pemberian tugas dan wewenang lebih dipercayakan kepada anggota formal dibandingkan anggota informal, dengan pertimbangan bahwa anggota informal kurang memiliki pengalaman dan penguasaan materi tentang prosedur pemerintahan. Praktik pemilihan Kepala Desa secara keseluruhan juga menunjukkan hasil yang tidak jauh berbeda dengan kelembagaan formal lebih efektif dibandingkan dengan kelembagaan informal. Perbedaan diantara keduanya muncul disebabkan oleh keterbatasan kontribusi faktor-faktor pengaruh pada tahap persiapan, tahap pelaksanaan, dan juga praktik secara keseluruhan. Hasil yang menunjukkan bahwa kelembagaan formal lebih efektif dibandingkan kelembagaan informal, telah menjawab hipotesis penelitian saya yang keempat, yakni kelembagaan formal lebih efektif dibandingkan kelembagaan informal.

\section{KESIMPULAN DAN SARAN}

\section{Kesimpulan}

Keempat faktor efektivitas yang terdiri dari faktor 
kelembagaan, faktor anggota kelembagaan, faktor sarana/ fasilitas pendukung, dan faktor sosial-masyarakat, faktor yang mempunyai pengaruh paling signifikan terhadap tingkat efektivitas adalah faktor anggota kelembagaan. Hasil ini telah menjawab hipotesis penelitian yang pertama yang menyatakan bahwa terdapat pengaruh signifikan faktor tertentu terhadap efektivitas kelembagaan.

Kemudian, dari keempat faktor efektivitas kelembagaan yang terdiri faktor kelembagaan, faktor anggota kelembagaan, faktor sarana/fasilitas pendukung, dan faktor sosialmasyarakat, terdapat satu faktor yang mempunyai pengaruh paling signifikan terhadap praktik pemilihan dibandingkan dengan ketiga faktor lainnya, yakni faktor sarana/fasilitas pendukung. Hal ini dikarenakan tingkat akses masyarakat terhadap informasi, akomodasi masyarakat, dan kontrol masyarakat terhadap proses berjalannya pemilihan Kepala Desa terbilang cukup kuat dan intens. Akses informasi, penyebaran informasi yang berkaitan dengan pemilihan Kepala Desa berjalan dengan sangat baik, dimana informasi yang diberikan bersifat transparan dan terbuka.

Selain itu, media penyebaran informasinya cukup beragam, seperti melalui selebaran yang ditempelkan di tempat-tempat yang strategis, penyaluran dari bapak RT/ RW setempat, serta penyaluran informasi di berbagai perkumpulan warga masyarakat. Penerimaan informasi pun merata di semua kalangan masyarakat. Di samping itu, akses kontrol masyarakat terhadap rangkaian proses pemilihan Kepala Desa terbilang baik, dari awal pembentukan panitia sampai pelantikan Kepala Desa, masyarakat benar-benar mengawal dan mengontrol kinerja panitia yang mana dikan ada ketimpangan yang terjadi. Hasil ini telah menjawab hipotesis penelitian yang kedua yang menyatakakan bahwa terdapat pengaruh signifikan faktor tertentu efektivitas kelembagaan dengan praktik pemilihan Kepala Desa.

Selanjutnya, tingkat efektivitas kelembagaan mempunyai pengaruh terhadap proses pemilihan Kepala Desa. Meski besarnya persentase pengaruh tidak melebihi angka $50 \%$, namun hasil tersebut telah dapat menjawab hipotesis penelitian yang ketiga, yaitu terdapat pengaruh antara efektivitas kelembagaan dengan praktik pemilihan Kepala Desa. Jika dilihat lebih jauh, tingkat efektivitas kelembagaan (formal maupun informal) dalam proses pemilihan Kepala Desa, nampaknya kelembagaan formal lebih efektif. Hal ini dikarenakan jumlah anggota formal yang dilibatkan dalam panitia pemilihan lebih banyak dibandingkan dengan jumlah anggota informal.

Selain itu, rata-rata usia anggota formal lebih muda dibandingkan dengan anggota informal, sehingga mempengaruhi keaktifan anggota dari segi tenaga fisik yang disalurkan. Usia yang lebih muda cenderung lebih gesit dan cekatan dibandingkan dengan anggota yang berusia lebih tua. Selanjutnya, rata-rata tingkat pendidikan pada kelembagaan formal pun lebih tinggi dibandingkan kelembagaan informal, sehingga mempengaruhi kapasitas dan kualitas sumberdaya manusia dalam menjalankan tugasnya. Hasil yang menunjukkan bahwa kelembagaan formal lebih efektif dibandingkan kelembagaan informal, telah menjawab hipotesis penelitian saya yang keempat, yakni kelembagaan formal lebih efektif dibandingkan kelembagaan informal.

\section{Saran}

Bagi kalangan akademisi, penelitian ini diharapkan dapat menambah khasanah penelitian mengenai kelembagaan yang efektif dalam praktik demokrasi desa. Penelitian ini juga diharapkan dapat menjadi acuan atau literatur bagi akademisi yang ingin meneliti lebih jauh mengenai kelembagaan-kelembagaan desa yang efektif dalam praktik demokrasi desa. Untuk penelitian selanjutnya, bisa dilihat dari aspek yang berbeda dari praktik pemilihan Kepala Desa, atau bisa diterapkan pada praktik penyelenggaraan desa yang lainnya.

Bagi pembuat kebijakan atau pihak pemerintahan, penelitian ini diharapkan dapat menjadi salah satu rujukan mengenai efektivitas kelembagaan dalam praktik demokrasi desa, yang selanjutnya dapat menjelaskan mengenai alasan efektif atau tidaknya kelembagaan yang ada di desa dalam melaksanakan praktik demokrasi desa. Melalui hasil penelitian ini, pemerintah diharapkan dapat mengawasi dan mengevaluasi lebih jauh lagi kinerja dari kelembagaan-kelembagaan desa dalam pelaksanaan demokrasi desa yang kemudian juga bisa meningkatkan kinerja dari kelembagaan-kelembagaan desa tersebut.Di samping itu, pemerintah daerah juga disarankan untuk melakukan pendisiplinan sistem pengangkatan pegawai/ pejabat pemerintahan, agar yang masuk dalam tata pemerintahan lokal maupun level di atasnya benar-benar yang berkompeten dan bermasyarakat.

Selanjutnya, bagi masyarakat, penelitian ini diharapkan dapat menambah pengetahuan mengenai efektivitas kelembagaan-kelembagaan desa dalam melaksanakan praktik demokrasi desa. Selain itu, pemerintah desa juga agar bisa melibatkan lebih banyak lagi dan memberikan kepercayaan pada anggota informal desa yang berusia muda dalam kegiatan penyelenggaraan pemerintahan desa, terutama praktik pemilihan Kepala Desa, serta dapat meningkatkan kapasitas dan kualitas anggota kelembagaan informal agar mereka bisa berkontribusi lebih banyak dan lebih aktif lagi. Pengawasan kinerja anggota formal desa tetap dipertahankan keaktifannya, dan lebih baik lagi untuk ditingkatkan.

\section{DAFTAR PUSTAKA}

[PERDA]. Peraturan Daerah Kabupaten Pemalang Nomor 7 Tahun 2010 tentang Pembentukan Lembaga Kemasyarakatan di Desa. 2010. [Dokumen]. [internet]. [diunduh pada tanggal 17 Desember 2013]. Dapat diunduh dari : http:// jdih.pemalangkab.go.id/produkhukum/asset/ PERDA\%20NOMOR\%207\%20TAHUN\%20 $2010 \% 20$ T T G\% 20 PER UB A H A N \% 20 ATAS $\% 20$ PERDA $\% 20$ KAB $\% 20$ PML $\% 20$ NOMOR\%206\%20TAHUN\%202007\%20 TTG\%20PEMBENTUKAN\%20LEMBAGA\%20 KEMASYARAKATAN\%20DI\%20DESA.pdf

[UU]. Undang-Undang Republik Indonesia Nomor 6 Tahun 2014 Tentang Desa. 2014. [Dokumen]. [internet]. [diunduh pada tanggal 22 Maret 2014]. Dapat diunduh dari : http://www.jdih.setjen.kemendagri. go.id/pm/UU\%20No.6\%20TH\%202014.pdf

Al-Hamdi R. 2011. Praktik Demokrasi Lokal di Indonesia, Studi Kasus di Kabupaten Lampung Tengah. J Studi 
Pemerintahan. [Internet]. [1 Oktober 2013]. 2(2): 331-352. Dapat diunduh dari : http://jsp.umy.ac.id

Anita K. 2013. Efektivitas Hukum dalam Pemberantasan Korupsi. Artikel. [internet]. [1 Desember 2013]. Dapat diunduh dari : http://id.scribd. com/doc/201303/efektivitas-hukum-dalampemberantasan-korupsi

Etzioni A. 1985. Modern Organization. Jusuf GR, Penyunting. Organisasi-Organisasi Modern. Jakarta [ID] : UI Press. 174 hal.

Gayatri IH. 2007. Demokrasi Lokal (di Desa) : Quo Vadis? Artikel. [Internet]. [30 September 2013]. Dapat diunduh dari : http://interseksi.org/publication/ articles/demokrasi lokal quo vadis.html

Hadiwinata BS. 2005. Civil Society : Pembangunan dan Sekaligus Perusak Demokrasi. J Ilmu Sosial dan Ilmu Politik. [Internet]. [4 Desember 2013]. 9(1): 1-22. Dapat diunduh dari : http://jsp.umy.ac.id

Hudayana B. 2003. Civil Society : Anatomi Perkembangan Perkumpulan Warga Di Era Otonomi. J Ilmu Sosial dan Ilmu Politik. [Internet]. [2 Desember 2013]. 6(3): 359-387. Dapat diunduh dari : http:// jurnalsospol.fisipol.ugm.ac.id/index.php/jsp/article/ view/171

Khairulludin. 2010. Effectiveness of Law Enforcement for Traffic and Transportation (Case Study Auto Bridge in Lubuk Selasih Kabupaten Solok). Working Paper. [Internet]. [13 Februari 2014]. Dapat diunduh dari : http://repository.unand.ac.id/1016/

Paraso A. 2013. Efektivitas Badan Permusyawaratan Desa dalam Penyelenggaraan Pengawasan Pemerintahan di Desa Sereh (Suatu Studi Di Desa Sereh Kecamatan Lirung Kabupaten Kepulauan Talaud. Jurnal Eksekutif. [Internet]. [13 Februari 2014]. dapat diunduh dari : https://ejournal.unsrat.ac.id/ index.php/jurnaleksekutif/article/view/2693

Prijono YM dan Tjiptoherijanto P. 2012. Demokrasi di Pedesaan Jawa. Jakarta [ID] : Kosa Kata Kita.

Rianse U dan Abdi. 2009. Metodologi Penelitian Sosial dan Ekonomi: Teori dan Aplikasi. Bandung [ID]: ALFABETA

Rikard R, Susanto A. 2005. Kewarganegaraan untuk SMP Kelas VIII. Jakarta [ID] : Erlangga.

Singarimbun M, Effendi S. 2006. Metode Penelitian Survai. Jakarta [ID] : LP3ES.

Utami BW, Molo M, Widiyanti E. [2011]. Efektivitas Kelembagaan dan Aliran Informasi untuk Optimalisasi Pengelolaan Lahan Surutan Bendungan Gajah Mungkur di Kabupaten Wonogiri. J-Sep. [Internet]. [13 Desember 2013]. 5(3). Dapat diunduh dari : http://jurnal.unej.ac.id/index.php/ JSEP/article/view/440/297 